\title{
APLIKASI EDIBLE COATING PATI SINGKONG PADA BUAH PEPAYA (Carica papaya L.) TEROLAH MINIMAL SELAMA PENYIMPANAN
}

\author{
Ifmalinda, Omil C. Chatib, dan Dini Megatama Soparani \\ Program Studi Teknik Pertanian, Fakultas Teknologi Pertanian Universitas Andalas \\ Email: ifmalinda@ae.unand.ac.id
}

\begin{abstract}
ABSTRAK
Buah pepaya sebelum dikonsumsi harus dikupas kulitnya dan bijinya dibuang. Pepaya yang sudah dikupas dan dipotong akan mudah mengalami kerusakan. Buah akan menjadi lunak dan lembek yang akan menyebabkan umur simpan akan menjadi lebih pendek serta akan mempengaruhi mutu dari buah pepaya. Upaya untuk mempertahankan mutu dan umur simpan buah papaya yang terolah minimal adalah mengendalikan proses fisiologis dan aktivitas mikroorganisme. Salah satu metode yang dilakukan untuk menghambat proses tersebut adalah dengan pelapisan edible coating. Tujuan penelitian adalah untuk menetukan konsentrasi edible coating pati singkong yang terbaik untuk mempertahankan mutu dan umur simpan pada buah pepaya terolah minimal. Penelitian ini menggunakan metode eksperimen dengan Rancangan Acak lengkap Faktorial yang terdiri dari perlakuan konsentrasi edible coating dan suhu penyimpanan. Hasil penelitian ini menunjukkan bahwa konsentrasi edible coating $2 \%$ pada penyimpanan suhu dingin merupakan konsentrasi terbaik untuk mempertahankan mutu buah pepaya terolah minimal selama penyimpanan.

Kata kunci-edible coating; penyimpanan; pati singkong; terolah minimal
\end{abstract}

\section{PENDAHULUAN}

Indonesia adalah negara yang beriklim tropis, banyak wilayah di Indonesia yang bisa dijadikan sebahagi lahan untuk budidaya buah-buahan. Letak geografis Indonesia yang berada di daerah khatulistiwa, juga menguntungkan bagi varietas buah-buahan untuk tetap lestari dan bisa dibudidayakan dengan baik. Buah pepaya sebelum dikonsumsi harus dikupas kulitnya dan bijinya dibuang. Pepaya yang sudah dikupas dan dipotong akan mudah mengalami kerusakan. Buah akan menjadi lunak dan lembek yang akan menyebabkan umur simpan akan menjadi lebih pendek serta akan mempengaruhi mutu dari buah pepaya. Upaya untuk mempertahankan mutu dan umur simpan buah papaya yang terolah minimal adalah mengendalikan proses fisiologis dan aktivitas mikroorganisme. Salah satu metode yang dilakukan untuk menghambat proses tersebut adalah dengan pelapisan edible coating. Lapisan yang digunakan pada permukaan kulit buah ini tidak berbahaya bila dikonsumsi karena bahan utamanya berasal dari tumbuh-tumbuhan dan hewan. Salah satu bahan edible coating yang dapat digunakan adalah pati singkong. Pati singkong relatif mudah didapat dan harganya murah. Pati singkong mengandung $83 \%$ amilopektin yang mengakibatkan pasta yang terbentuk menjadi bening dan kemungkinan untuk terjadi retrogradasi adalah kecil (Friedman 1950 dalam Dehya 2015).

Pati singkong sebagai bahan baku pembuatan edible singkong sudah digunakan pada pisang Cavendish untuk memperpanjang umur simpan. Penggunaan edible coating dengan komposisi pati singkong 3\% terbukti dapat memperpanjang umur simpan pisang tersebut selama delapan hari, dua hari lebih lama dari pada kontrol (tanpa pelapisan edible coating). Erica (2011) menggunakan $\mathrm{Cacl}_{2}$ terhadap warna dan citra rasa buah pepaya kupas menggunakan edible coating dengan komposisi $\mathrm{CaCl}_{2} 3 \%$ pada penyimpanan suhu kamar dapat memperpanjang umur simpan buah pepaya selama 27 jam (Budiman, 2011). Penelitian ini bertujuan untuk menentukan konsentrasi edible coating berbasis pati singkong yang terbaik untuk mempertahankan mutu dan umur simpan pepaya (Carica papaya L.)

\section{METODOLOGI PENELITIAN}

\section{A. Bahan dan Alat}

Bahan yang digunakan dalam penelitian ini adalah buah pepaya jenis California dengan indeks kematangan 5 (matang sedang), pati singkong, carboxymethylcellulose (CMC), gliserol 5\%, potassium sorbat $0.5 \%$ dan aquades. Peralatan yang digunakan adalah thermometer, refractometer, 
forge gauge, timbangan digital, mesin pendingin (refrigerator), gelas ukur, erlenmeyer, pipet tetes, kamera digital, pengaduk, baskom, tray, kertas saring, stopwatch, cutter, dan periuk.

\section{B. Metode Penelitian}

Metode yang digunakan dalam penelitian ini adalah Rancangan Acak Lengkap Faktorial yang terdiri dari dua perlakuan yaitu kosentrasi edible dan suhu penyimpanan. Kosentrasi edible terdiri dari empat taraf kosentrasi edible coating yaitu kontrol, $2 \%, 4 \%$, dan $6 \%$ dan dua taraf suhu yaitu suhu ruang dan suhu dingin $\left(10^{\circ}\right)$ dengan 5 kali ulangan.

\section{Pelaksanaan Penelitian}

Pelarutan carboxymethylcellulose (CMC) sebanyak $0.4 \% \mathrm{~b} / \mathrm{v}$ diaduk pada suhu $70^{\circ} \mathrm{C}$ hingga homogen selanjutnya penambahan pati singkong dengan masing-masing kosentrasi pati singkong adalah $2 \%, 4 \%$ dan $6 \%$ diaduk pada suhu $70^{\circ} \mathrm{C}$ hingga homogen. Gliserol ditambahkan sebanyak $5 \%$ $\mathrm{v} / \mathrm{v}$ diaduk pada suhu $70^{\circ} \mathrm{C}$ selama \pm 1 menit. Potassium sorbat sebanyak $0.5 \% \mathrm{~b} / \mathrm{v}$ diaduk pada suhu $70^{\circ} \mathrm{C}$ hingga homogen. Buah pepaya terolah minimal dicelupkan ke dalam 3 formula larutan pelapis edible coating yang berbeda, yakni edible coating dengan kosentrasi $2 \%$, kosentrasi $4 \%$, kosentrasi $6 \%$ selama 30 detik kemudian ditiriskan selama 10 detik. Setelah itu buah pepaya dikeringkan di atas tray berlubang pada suhu ruang selama 10 menit (Dehya, 2015).

\section{Pengamatan}

1. Kekerasan

Kekerasan buah pepaya diukur dengan menggunakan alat force gauge. Bahan yang akan diuji diletakkan tepat di bawah jarum. Pengukuran kekerasan pepaya dilakukan pada tiga bagian yang berbeda yaitu pangkal, tengah, dan ujung. Kekerasan buah dinyatakan dalam satuan Newton.

\section{Susut Bobot}

Pengukuran susut bobot buah pepaya dilakukan dengan membandingkan selisih bobot setiap akhir penyimpanan (Wt) dibandingkan dengan susut bobot awal sebelum penyimpanan atau penerimaan (Wo), seanjutnya susut bobot dihitung dengan menggunakan rumus sebagai berikut:

$\mathrm{Sb}=\frac{\left[\cdot \mathrm{t}-W^{2} o\right.}{W^{2} o} \times 100 \%$

Keterangan:

$\mathrm{Sb}=$ Susut bobot pepaya (\%)

Wo = Berat sebelum penyimpanan pepaya $(\mathrm{g})$

$\mathrm{Wt} \quad=$ Berat sesudah penyimpanan pepaya $(\mathrm{g})$

\section{Total Padatan Terlarut}

Pengukuran total padatan terlarut dilakukan dengan menggunakan refractometer. Cairan dari bahan diteteskan di atas kaca refractometer. Refractometer diarahkan ke cahaya untuk melihat nilai di dalamnya, pengambilan nilai dilakukan dengan 5 kali ulangan dengan mengambil cairan dari beberapa sisi bahan yang berbeda yaitu pangkal pepaya, ujung pepaya, dan tengah pepaya. Nilai yang didapatkan dinyatakan dalam satuan ${ }^{\circ}$ Brix. Pengamatan total padatan terlarut dilakukan setiap harinya.

\section{Uji Vitamin C (Jacobs 1959 dalam Mardiana 2008)}

25 gram bahan dihancurkan dalam blender. Kemudian dimasukkan dalam labu ukur $250 \mathrm{ml}$, encerkan sampai tanda tera dengan menambah air destilata yang digunakan sebagai pembilas blender, selanjutnya disaring menggunakan kertas saring. Filtrat yang diperoleh sebanyak $25 \mathrm{ml}$ dimasukkan ke dalam erlenmeyer, ditambahkan 2-3 tetes pati 1\%, kemudian dititrasi dengan larutan iod 0,01 N sampai timbul perubahan warna yang stabil (biru ungu). Setiap $\mathrm{ml}$ iod sebanding dengan $0,88 \mathrm{mg}$ asam askorbat, sehingga kadar asam askorbat (vitamin C) dari bahan dapat dihitung dengan rumus:

Vitamin $C=\left(\frac{m g}{100 \text { gbahan }}\right)=\frac{m i \text { iod } \times 0.88 \times F \times 100}{g \text { sampei }}$ 
Keterangan: $\mathrm{F}$

$1 \mathrm{ml} 0.01 \mathrm{~N}$ iodine
$=$ Faktor pengenceran

$=0.88 \mathrm{mg}$ asam askorbat

\section{Ion Leakage (Fahmy dan Nakano, 2014)}

Ion leakage dihitung dengan menggunakan metode yang dijelaskan oleh Saltveit (2002) dalam Fahmy dan Nakano (2014) dengan beberapa modifikasi. Bagian mesocarp pepaya diambil dengan cara dipotong dengan diameter $4 \mathrm{~mm}$. Sampel kemudian direndam dengan aquades $(40 \mathrm{ml})$ untuk menghilangkan kelebihan ion pada permukaan jaringan. Perlakuan ini diulang sebanyak 3 kali, setelah itu sampel disaring dengan kertas saring untuk menghilangkan kandungan air. Kemudian sampel dimasukkan ke dalam tabung plastik $50 \mathrm{ml}$ dengan volume manitol $20 \mathrm{ml}$ pada konsentrasi $0.2 \mathrm{~m}$. Nilai konduktivitas diukur dengan conductivity meter selama 30 menit setelah sampel dimasukkan ke dalam larutan manitol. Tabung kemudian didinginkan dan dicairkan dengan cara direbus selama 10 menit. Kemudian didinginkan dan total ion dihitung dengan conductivity meter. Pengamatan dilakukan 3 kali ulangan dengan pengambilan data setip hari sampai pepaya tidak layak dikonsumsi. Persentase ion leakage dihitung dengan persamaan:

$\mathrm{Ec}=\frac{E s-E \mathrm{~m}}{\varepsilon T-E m} \times 100 \%$

Keterangan:

$\mathrm{E}_{\mathrm{c}}=$ ion leakage $(\%)$

$\mathrm{E}_{\mathrm{m}}=$ conductivity manitol $(\mathrm{mS} / \mathrm{cm}($ mili-siemens per $\mathrm{cm}))$

$\mathrm{E}_{\mathrm{s}}=$ conductivity sampel $(\mathrm{mS} / \mathrm{cm}($ mili-siemens per $\mathrm{cm}))$

$\mathrm{E}_{\mathrm{T}}=$ conductivity total $(\mathrm{mS} / \mathrm{cm}($ mili-siemens per $\mathrm{cm}))$

\section{Uji Organoleptik (Sugito, 2014)}

Uji organoleptik merupakan uji lanjutan dengan indera manusia sebagai alat utama untuk pengukuran daya terima terhadap produk. Prosesnya menguji bahan menggunakan responden untuk mencoba bahan sesuai dengan kriteria yang diberikan. Responden akan memberikan penilaian sesuai dengan yang mereka rasa. Kriteria yang akan diuji meliputi warna dan rasa. Penilaian memiliki rentang nilai yang berkisar dari 1-5 dengan urutan sebagai berikut: $1=$ tidak suka, $2=$ kurang suka, $3=$ agak suka, $4=$ suka, 5 = sangat suka.

\section{HASIL DAN PEMBAHASAN}

\section{A. Kekerasan}

Nilai kekerasan pepaya terolah minimal mengalami penurunan pada semua perlakuan seperti terlihat pada Gambar 1. Apabila semakin lama penyimpanan maka nilai kekerasan buah pepaya terolah minimal semakin menurun artinya semakin lunak. Hal ini sejalan dengan (Winarno 1997 dalam Mardiana 2008), semakin lama buah disimpan maka akan semakin lunak disebabkan oleh degradasi senyawa-senyawa penyusun dinding sel buah. Secara kimiawi, dinding sel tersusun oleh senyawa-senyawa kompleks namun pada umunya terdiri dari selulosa, lignin dan pektin. Terjadinya degradasi ini disebabkan adanya beberapa cendawan dan bakteri yang menghidrolisa selulosa menjadi senyawa yang lebih sederhana. Hal ini disebabkan selama penyimpanan buah pepaya terolah minimal mengalami perubahan kematangan sehingga tingkat kekerasan buah berubah.

Penyimpanan pada suhu ruang hanya bisa diamati pada hari ke-0. Konsentrasi yang mampu menjaga nilai kekerasan buah pepaya pada suhu ruang adalah konsentrasi $2 \%$. Hal ini karena pada suhu ruang proses metabolisme mengalami peningkatan dan buah pepaya terolah minimal mengalami kematangan sehingga tingkat kekerasan buah semakin lunak dibandingkan suhu dingin. Menurut Kismaryanti (2007), suhu penyimpanan berpengaruh terhadap nilai kekerasan dimana penyimpanan pada suhu dingin dapat mempertahankan keutuhan dinding sel dan turgor sel lebih baik jika dibandingkan pada suhu ruang.

Pepaya yang tidak dilapisi edible coating memiliki tingkat kekerasan yang kecil dibandingkan dengan yang diberi pelapis. Hal ini sejalan dengan (Sari, 2015) yang mengatakan buah stroberi kontrol mengalami penurunan nilai kekerasan lebih cepat dibandingkan dengan buah yang diberi 
perlakuan. Hal ini sejalan dengan Megaria (2011) yang mengatakan perlakuan pelapisan diduga dapat menutup stomata buah sehingga dapat menghambat proses metabolisme produk. Nilai kekerasan buah pepaya terolah minimal yang paling tinggi terdapat pada perlakuan $2 \%$ baik disimpan pada suhu ruang maupun suhu dingin. Melihat pengaruh perbedaan konsentrasi dan suhu penyimpanan terhadap nilai kekerasan maka dilakukan analisis varian (ANOVA) yang dapat dilihat pada Tabel 1 .

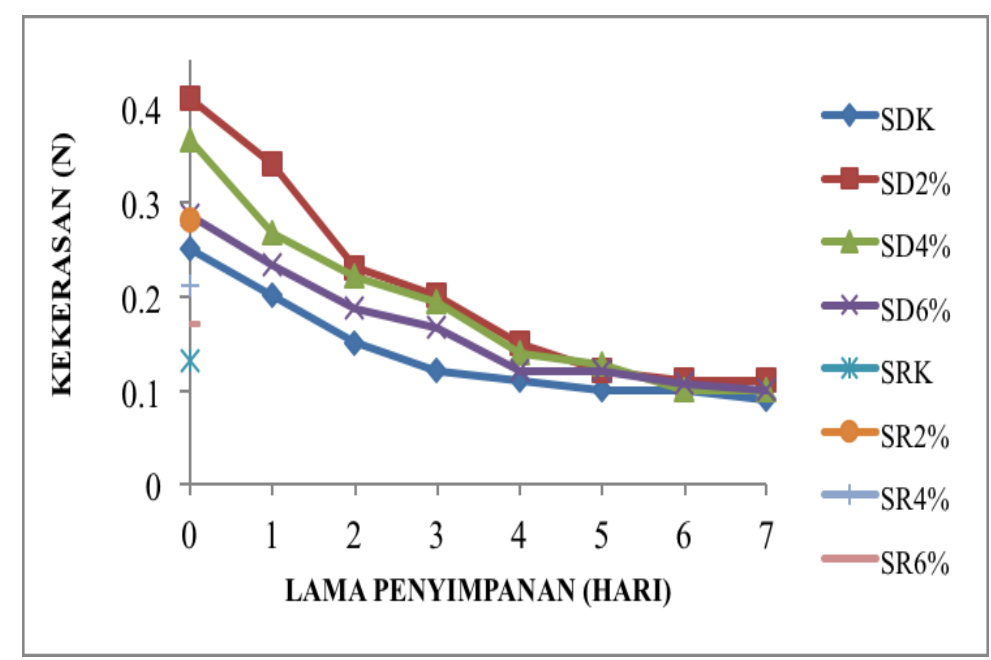

Gambar 1. Kekerasan Buah Pepaya Terolah Minimal pada masing-masing Suhu dan Konsentrasi Edible

Tabel 1. Analisis Anova pada Perubahan Nilai Kekerasan

\begin{tabular}{lccccc}
\hline Parameter Pengamatan & Jumlah Kuadrat & Derajat Bebas & Kuadran Tengah & F.Hitung & Sig. \\
\hline Suhu_Penyimpanan & 0,186 & 1 & 0,186 & 40,110 & 0,000 \\
Konsentrasi_Edible & 0,095 & 3 & 0,032 & 6,853 & 0,000 \\
Hari_Penyimpanan & 0,979 & 7 & 0,140 & 30,122 & 0,000 \\
Suhu_Penyimpanan * & 0,002 & 3 & 0,001 & 0,149 & 0,930 \\
Konsentrasi_Edible & & & & & \\
Konsentrasi_Edible* & 0,072 & 21 & 0,003 & 0,740 & 0,786 \\
Hari_Penyimpanan & & & & & \\
Suhu_Penyimpanan * & 0,000 & 0 & & & $\cdot$ \\
Hari_Penyimpanan & & & & & \\
$\begin{array}{l}\text { Suhu_Penyimpanan * } \\
\text { Konsentrasi_Edible* }\end{array}$ & 0,000 & 0 & & & \\
Hari_Penyimpanan & & & & & \\
\hline
\end{tabular}

Hasil sidik ragam menyatakan bahwa nilai kekerasan buah pepaya terolah minimal dengan konsentrasi edible 0,000 yang lebih kecil dari 0,05 maka $\mathrm{H}_{0}$ ditolak dan $\mathrm{H}_{1}$ diterima, artinya perbedaan konsentrasi edible berpengaruh terhadap nilai kekerasan buah pepaya terolah minimal. Pada suhu penyimpanan nilai signifikannya 0,000 yang lebih kecil dari 0,05 maka $\mathrm{H}_{0}$ ditolak dan $\mathrm{H}_{1}$ diterima, artinya ada pengaruh suhu penyimpanan terhadap nilai kekerasan buah pepaya terolah minimal. pada hari penyimpanan nilai signifikannya 0,000 yang lebih kecil dari 0,05 maka H0 ditolak dan $\mathrm{H} 1$ diterima, yang artinya ada pengaruh hari penyimpanan terhadap nilai kekerasan buah pepaya.

\section{B. Susut Bobot}

Nilai susut bobot buah pepaya terolah minimal mengalami peningkatan setiap harinya seperti terlihat pada Gambar 2. Hari ke-0 sampai hari ke 1 tidak ada perubahan susut bobot yang sigifikan pada suhu dingin. Akan tetapi setelah hari ke-1 penyimpananbuah pepaya dengan konsentrasi kontrol, $4 \%$ dan $6 \%$ meningkat lebih besar dibandingkan dengan konsentrasi $2 \%$. Ini membuktikan bahwa konsentrasi $2 \%$ adalah konsentrasi yang cocok untuk mempertahaankan susut bobot buah pepaya 
selama 7 hari penyimpanan. Penyimpanan suhu ruang hanya bisa diamati pada hari ke- 0 . Konsentrasi yang memiliki persentase susut bobot paling kecil adalah konsentrasi $2 \%$. Susut bobot hari ke - 1 dan seterusnya pada suhu ruang tidak dapat diukur lagi ini disebabkan buah pepaya terolah minimal telah mengalami kerusakan seperti cacat dan berjamur.

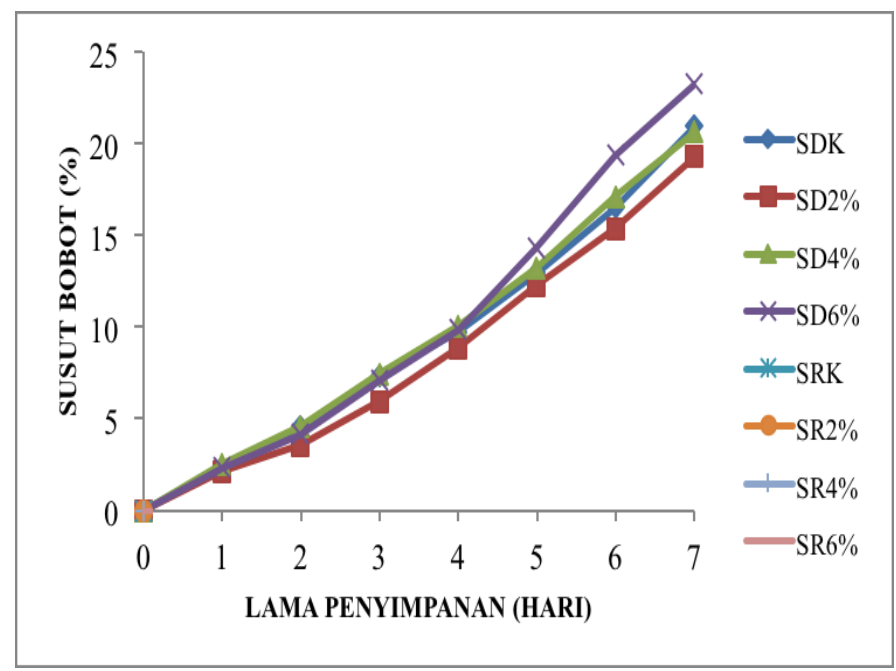

Gambar 2. Susut Bobot Buah Pepaya Terolah Minimal pada masing-masing Suhu dan Konsentrasi Edible

Buah pepaya terolah minimal yang tidak diberi pelapis mengalami penurunan susut bobot lebih cepat dibandingkan dengan yang diberi pelapis. Hal ini sejalan dengan Megaria (2011) yang mengatakan bahwa pelapisan mampu menutup stomata pada buah belimbing sehingga proses penguapan dan pernapasan dari buah lebih kecil yang mengakibatkan perubahan persentase susut bobot buahnya lebih rendah. Hal ini didukung Herdiana (2010) megatakan bahwa perlakuan pelapisan aloe vera $100 \%$ memiliki kemampuan dalam menghambat terjadinya proses respirasi dan transpirasi. Melihat pengaruh perbedaan konsentrasi dan suhu penyimpanan terhadap susut bobot maka dilakukan analisis varian (ANOVA) yang dapat dilihat pada Tabel 2.

Tabel 2. Analisis Anova pada Perubahan Susut Bobot

\begin{tabular}{lccccc}
\hline \multicolumn{1}{c}{ Parameter Pengamatan } & Jumlah Kuadrat & Derajat Bebas & Kuadran Tengah & F.Hitung & Sig. \\
\hline Suhu_Penyimpanan & 0,000 & 1 & 0,000 & 0,000 & 1,000 \\
Konsentrasi_Edible & 27,226 & 3 & 9,075 & 1,092 & 0,354 \\
Hari_Penyimpanan & 7607,653 & 7 & 1086,808 & 130,802 & 0,000 \\
Suhu_Penyimpanan * & 0,000 & 3 & 0,000 & 0,000 & 1,000 \\
$\begin{array}{l}\text { Konsentrasi_Edible } \\
\text { Konsentrasi_Edible * }\end{array}$ & 55,131 & 21 & 2,625 & 0,316 & 0,998 \\
$\begin{array}{l}\text { Hari_Penyimpanan } \\
\text { Suhu_Penyimpanan * }\end{array}$ & 0,000 & 0 & & & \\
$\begin{array}{l}\text { Hari_Penyimpanan } \\
\text { Suhu_Penyimpanan * }\end{array}$ & 0,000 & 0 & & & $\cdot$ \\
Konsentrasi_Edible* & & & & & $\cdot$ \\
Hari_Penyimpanan & & & & & \\
\hline
\end{tabular}

Hasil sidik ragam menunjukkan bahwa nilai susut bobot buah pepaya terolah minimal dengan kosnsentrasi edible 0,354 yang lebih besar dari 0,05 maka $\mathrm{H}_{0}$ diterima dan $\mathrm{H}_{1}$ ditolak, artinya perbedaan konsentrasi edible tidak memberikan pengaruh terhadap susut bobot, sedangkan pada suhu penyimpanan nilai signifikannya 1,000 yang lebih besar dari 0,05 maka $\mathrm{H}_{0}$ diterima dan $\mathrm{H}_{1}$ ditolak, artinya tidak ada pengaruh suhu penyimpanan terhadap susut bobot. Pada hari penyimpanan nilai signifikan yang didapatkan sebesar 0,000 kecil dari 0,05 artinya ada pengaruh hari penyimpanan terhadap nilai kekerasan. 


\section{Total Padatan Terlarut}

Nilai total padatan terlarut buah pepaya terolah minimal meningkat pada semua perlakuan seperti terlihat pada Gambar 3.. Penyimpanan pada suhu dingin menunjukkan hari pertama nilai total padatan terlarut meningkat pada semua perlakuan. Hari kedua nilai total pada terlarut meningkat pada semua perlakuan juga. Konsentrasi yang memiliki nilai total padat terlaru tertinggi terdapat pada konsentrasi $2 \%$. Penyimpanan pada suhu dingin hanya bisa diamati pada hari ke- 0 . Hari selanjutnya pengamatan serta pengukuran total padatan terlarut untuk penyimpanan suhu ruang tidak dapat dilakukan lagi, hal ini dikarenakan buah pepaya terolah minimal telah mengalami kerusakan dan telah ditumbuhi jamur.

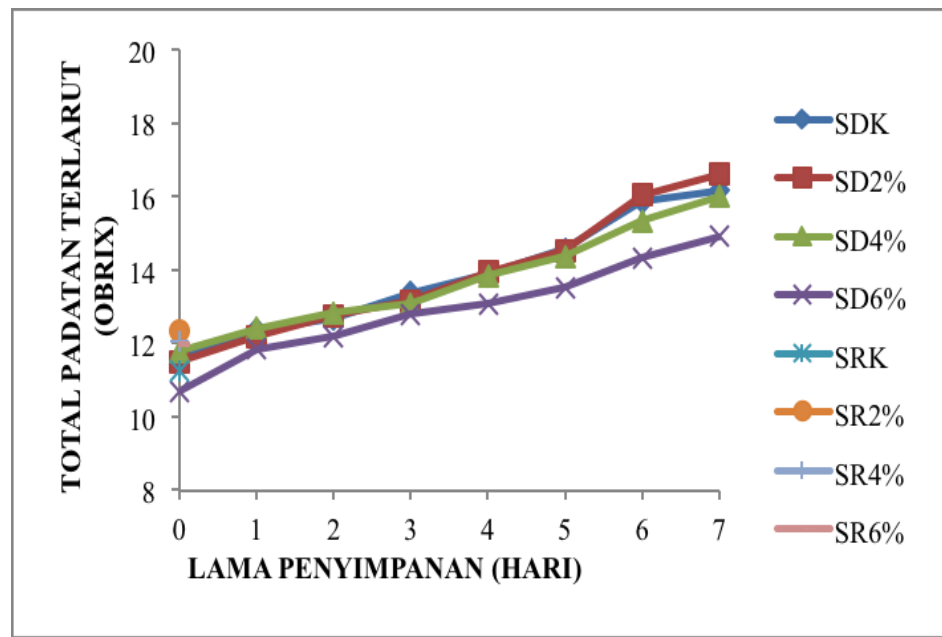

Gambar 3. Total Padatan Terlarut Buah Pepaya Terolah Minimal pada masing-masing Suhu dan Konsentrasi Edible

Konsentrasi edible coating 2\% memiliki nilai padatan terlarut tertinggi diantara semua perlakuan terbukti sampai akhir penyimpanan. Hal ini sejalan dengan (Baldwin et al., 1997 dalam Bujianova 2017) menyatakan bahwa pelapisan dapat menghambat laju metabolisme polisakharisa sehingga kandungan gula buah dapat dipertahankan. Buah mengalami pematangan dan terjadi perubahan oksidatif dari bahan-bahan kompleks, seperti karbohidrat, protein dan lemak sehingga terbentuk gula-gula sederhana yaitu gluktosa, fruktosa dan sukrosa. Menurut Winarno (2002), peningkatan total gula terjadi karena akumulasi gula sebagai hasil degradasi pati, karena selama pematangan terjadi hidrolisa polisakarida menjadi gula-gula sederhana, sedangkan penurunan total gula terjadi karena sebagian gula digunakan untuk proses respirasi, karena gula tersebut digunakan untuk menghasilkan energi. Melihat pengaruh perbedaan konsentrasi dan suhu penyimpanan terhadap total padatan terlarut maka dilakukan analisis varian (ANOVA) yang dapat dilihat pada Tabel 3.

Tabel 3. Analisis Anova pada perubahan Nilai Total Padatan Terlarut

\begin{tabular}{lccccc}
\hline \multicolumn{1}{c}{ Parameter Pengamatan } & Jumlah Kuadrat & Derajat Bebas & Kuadrat Tengah & F.Hitung & Sig. \\
\hline Suhu_Penyimpanan & 2,669 & 1 & 2,669 & 2,698 & 0,103 \\
Konsentrasi Edible & 8,525 & 3 & 2,842 & 2,872 & 0,038 \\
Hari_Penyimpanan & 342,189 & 7 & 48,884 & 49,403 & 0,000 \\
Suhu_Penyimpanan * Edibel & 3,853 & 3 & 1,284 & 1,298 & 0,278 \\
Suhu_Penyimpanan * & 0,000 & 0 &. &. & . \\
Hari_Penyimpanan & & & & & \\
Edibel *Hari_Penyimpanan & 6,676 & 21 & 0,318 & 0,321 & 0,998 \\
Suhu_Penyimpanan * Edibel & 0,000 & 0 &. & &. \\
*Hari_Penyimpanan & & & & & \\
\hline
\end{tabular}


Hasil sidik ragam menujukkan bahwa nilai signifikan total padatan terlarut buah pepaya terolah minimal dengan konsentrasi edible sebesar 0,038 yang lebih kecil dari 0,05 maka $\mathrm{H}_{0}$ ditolak dan $\mathrm{H}_{1}$ diterima, artinya perbedaan konsentrasi memberikan pengaruh terhadap total padatan terlarut, sedangkan pada suhu penyimpanan nilai signifikannya 0,103 yang lebih besar dari 0,05 maka $\mathrm{H}_{0}$ diterima dan $\mathrm{H}_{1}$ ditolak, artinya tidak ada pengaruh suhu penyimpanan terhadap total padatan terlarut. Pada hari penyimpanan nilai signifikan sebesar 0,000 lebih kecil dari 0,005 artinya ada pengaruh hari penyimpanan terhadap nilai total padatan terlarut.

\section{Kandungan Vitamin C}

Nilai vitamin $C$ buah pepaya terolah minimal mengalami penurunan selama penyimpanan pada semua perlakuan seperti yang terlihat pada Gambar 4. Penyimpan suhu dingin nilai vitamin $\mathrm{C}$ pada perlakuan kontrol, $2 \%, 4 \%$, dan $6 \%$ mengalami penurunan. Hari ketiga untuk semua perlakuan memiliki nilai vitamin $\mathrm{C}$ rata-rata yang sama. Hari ke- 6 dan ke-7 nilai vitamin C konsentrasi 2\% masih terbaik diantara semua perlakuan. Hal ini membuktikan bahwa konsentrasi $2 \%$ mampu menjaga kandungan vitamin $\mathrm{C}$ di dalam pepaya. Penyimpanan suhu ruang hanya bisa diamati pada hari ke-0. Konsentrasi $2 \%$ memiliki kandungan vitamin $\mathrm{C}$ yang tinggi diantara semua perlakuan. Hari selanjutnya pengamatan serta pengukuran kandungan vitamin $C$ untuk penyimpanan suhu ruang tidak dapat dilakukan lagi, hal ini dikarenakan buah pepaya terolah minimal telah mengalami kerusakan dan telah ditumbuhi jamur.

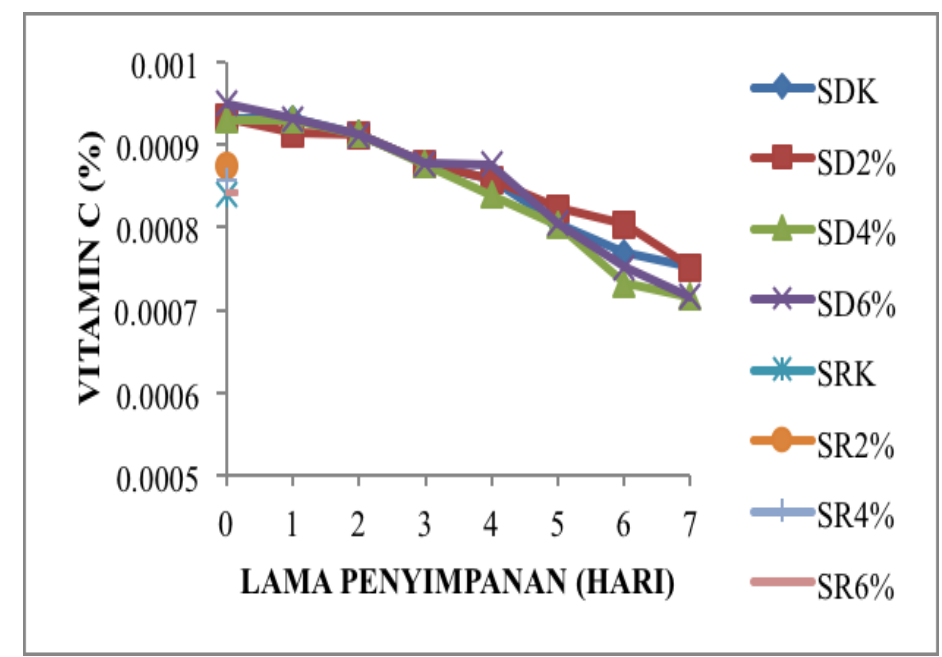

Gambar 4. Vitamin C Buah Pepaya Terolah Minimal pada masing-masing Suhu dan Konsentrasi Edible

Selama proses pematangan akan terjadi penurunan asam-asam organik, penurunan organik ini diduga disebabkan oleh penggunaan asam organik pada proses respirasi atau mengalami konversi menjadi gula (Pujimulyani, 2009). Kandungan vitamin C pada perlakuan kontrol memiliki penurunan yang lebih tinggi. Hal ini dikarenakan pada buah pepaya terolah minimal yang tidak diberi pelapis, difusi $\mathrm{O}_{2}$ ke dalam jaringan tidak dapat dihambat, yang mangakibatkan degradasi vitamin $\mathrm{C}$ akan terus berkembang. Terdregadasinya vitamin $\mathrm{C}$ ini menyebabkan penurunan kandungannya dalam buah. Menurut Donhowe dan Fennema (1994) dalam Krochta et al. (1994), bahan dasar edible coating yang bersifat hidrofilik (seperti karagenan) memiliki sifat penghalang yang baik terhadap oksigen, karbondioksida, lipida. Adanya lapisan edible coating dapat menekan masuknya oksigen ke dalam buah yang menjadi penyebab rusaknya vitamin $\mathrm{C}$ lewat reaksi oksidasi. Hal ini sejalan dengan Rudito (2005), adanya pelapisan pada buah tomat dapat menghambat laju respirasi. Melihat pengaruh perbedaan konsentrasi dan suhu penyimpanan terhadap Vitamin $\mathrm{C}$ maka dilakukan analisis varian (ANOVA) yang dapat dilihat pada Tabel 4. 
Tabel 4. Analisis Anova pada perubahan Nilai Kandungan Vitamin C

\begin{tabular}{|c|c|c|c|c|c|}
\hline Parameter Pengamatan & Jumlah Kuadrat & Derajat Bebas & Kuadran Tengah & F.Hitung & Sig. \\
\hline Suhu_Penyimpanan & $6,798 \mathrm{e}-8$ & 1 & $6,798 \mathrm{e}-8$ & 26,948 & 0,000 \\
\hline Konsentrasi_Edible & $6,550 e-9$ & 3 & $2,183 \mathrm{e}-9$ & 0,865 & 0,461 \\
\hline Hari_Penyimpanan & $8,163 e-7$ & 7 & $1,166 \mathrm{e}-7$ & 46,224 & 0,000 \\
\hline $\begin{array}{l}\text { Suhu_Penyimpanan * } \\
\text { Konsentrasi_Edible }\end{array}$ & $3,625 \mathrm{e}-9$ & 3 & $1,208 \mathrm{e}-9$ & 0,479 & 0,697 \\
\hline $\begin{array}{l}\text { Konsentrasi_Edible * } \\
\text { Hari_Penyimpanan }\end{array}$ & $2,133 \mathrm{e}-8$ & 21 & $1,016 \mathrm{e}-9$ & 0,403 & 0,991 \\
\hline $\begin{array}{l}\text { Suhu_Penyimpanan * } \\
\text { Hari_Penyimpanan }\end{array}$ & 0,000 & 0 & & . & \\
\hline $\begin{array}{l}\text { Suhu_Penyimpanan * } \\
\text { Konsentrasi_Edible * } \\
\text { Hari_Penyimpanan }\end{array}$ & 0,000 & 0 & & . & \\
\hline
\end{tabular}

Hasil sidik ragam menunjukkan bahwa nilai signifikan kandungan vitamin $\mathrm{C}$ buah pepaya terolah minimal dengan konsentrasi edible 0,461 yang lebih besar dari 0,05 maka $\mathrm{H}_{0}$ diterima dan $\mathrm{H}_{1}$ ditolak, artinya perbedaan kosnsentrasi tidak memberikan pengaruh terhadap vitamin c, sedangkan pada suhu penyimpanan nilai signifikannya 0,000 yang lebih kecil dari 0,05 maka $\mathrm{H}_{0}$ ditolak dan $\mathrm{H}_{1}$ diterima, artinya ada pengaruh suhu penyimpanan terhadap vitamin c. Pada hari penyimpanan nilai signifikan sebesar 0.000 lebih kecil dari 0,05 artinya, ada pengaruh hari penyimpanan terhadap kandungan vitamin $\mathrm{C}$.

\section{E. Ion Leakage}

Kenaikan persentase ion leakage menunjukkan besarnya membran sel yang pecah. Penyimpanan suhu dingin hari ke-0 nilai ion leakage berbeda-beda dikarenakan pada hari ke-0 sudah diberi perlakuan dengan konsentrasi kontrol, 2\%, 4\% dan 6\%. Nilai ion leakage mulai dari hari pertama sampai hari ketujuh penyimpanan mengalami peningkatan seperti terlihat pada Gambar 5 . Konsentrasi $2 \%$ adalah perlakuan yang paling kecil kenaikkan ion leakagenya dibandingkan dengan perlakuan konsentrasi kontrol, $2 \%, 4 \%$ dan $6 \%$ selama penyimpanan. Penyimpanan pada suhu ruang hanya bisa diamati pada hari ke-0. Hari selanjutnya pengamatan serta pengukuran ion leakage untuk penyimpanan suhu ruang tidak dapat dilakukan lagi, hal ini dikarenakan buah pepaya terolah minimal telah mengalami kerusakan serta telah ditumbuhi jamur. Pada suhu ruang nilai ion leakage konsentrasi $2 \%$ paling kecil diantara kontrol, $4 \%$ dan $6 \%$. Hal ini membuktikan bahwa konsentrasi $2 \%$ pada suhu ruang bisa mencegah kerusakan.

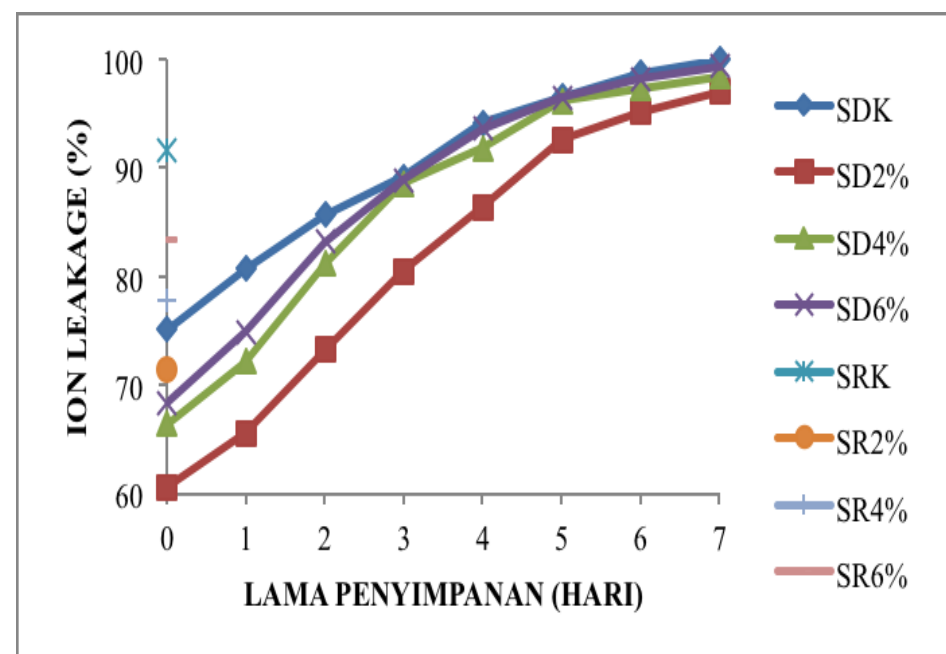

Gambar 5. Ion Leakage Buah Pepaya Terolah Minimal pada masing-masing Suhu dan Konsentrasi Edible 
Buah pepaya terolah minimal yang tidak diberi pelapis memiliki kenaikan ion leakage yang lebih tinggi dibandingkan dengan yang diberi pelapis. Hal ini sejalan dengan Megaria (2011) yang menyatakan buah belimbing dewa tanpa perlakuan aloe vera coating cenderung mengalami peningkatan persentase ion leakage lebih besar apabila dibandingkan dengan buah belimbing dewa dengan perlakuan aloe vera coating. Melihat pengaruh perbedaan konsentrasi dan suhu penyimpanan terhadap ion leakage maka dilakukan analisis varian (ANOVA) yang dapat dilihat pada Tabel 5 .

Tabel 5. Analisis Anova pada perubahan Nilai Kandungan Ion Leakage

\begin{tabular}{lccccc}
\hline \multicolumn{1}{c}{ Parameter Pengamatan } & Jumlah Kuadrat & Derajat Bebas & Kuadran Tengah & F.Hitung & Sig. \\
\hline Konsentrasi Edible & 1151,392 & 3 & 383,797 & 17,462 & 0,000 \\
Hari_Penyimpanan & 11207,901 & 7 & 1601,129 & 72,850 & 0,000 \\
Suhu_Penyimpanan & 1081,842 & 1 & 1081,842 & 49,223 & 0,000 \\
Edible* Suhu_Penyimpanan & 33,487 & 3 & 11,162 & 0,508 & 0,678 \\
Suhu_Penyimpanan * & 0,000 & 0 & $\cdot$ & $\cdot$ & $\cdot$ \\
Hari_Penyimpana & & & 14,842 & 0,675 & 0,843 \\
Edible* Hari_Penyimpana & 311,674 & 21 &. & $\cdot$ \\
Edible* Suhu_Penyimpanan & 0,000 & 0 & &. \\
$*$ Hari_Penyimpana & & & & \\
\hline
\end{tabular}

Hasil sidik ragam menunjukkan bahwa nilai signifikan ion leakage buah pepaya terolah minimal dengan konsentrasi edible 0,000 yang berarti lebih kecil dari 0,05 maka $\mathrm{H}_{0}$ ditolak dan $\mathrm{H}_{1}$ diterima, artinya perbedaan konsentrasi berpengaruh terhadap ion leakage, sedangkan nilai signifikan suhu penyimpanan sebesar 0,000 yang lebih kecil dari 0,05 maka $\mathrm{H}_{0}$ ditolak dan $\mathrm{H}_{1}$ diterima yang artinya ada pengaruh suhu penyimpanan terhadap ion leakage. Pada hari penyimpanan nilai signifikan sebesar 0,000 lebih kecil dari 0,05 yang artinya ada pengaruh hari penyimpanan terhadap ion leakage.

\section{F. Uji Organoleptik \\ 1. Warna}

Uji organoleptik mengalami penurunan setiap harinya seperti yang terlihat pada Gambar 6 . Pada penyimpanan dindin pepaya yang dilapisi edible coating dengan konsentrasi $4 \%$ merupakan buah pepaya terolah minimal yang paling tidak disukai panelis dibandingkan dengan konsentrasi $6 \%$, $2 \%$ dan tanpa pelapis.

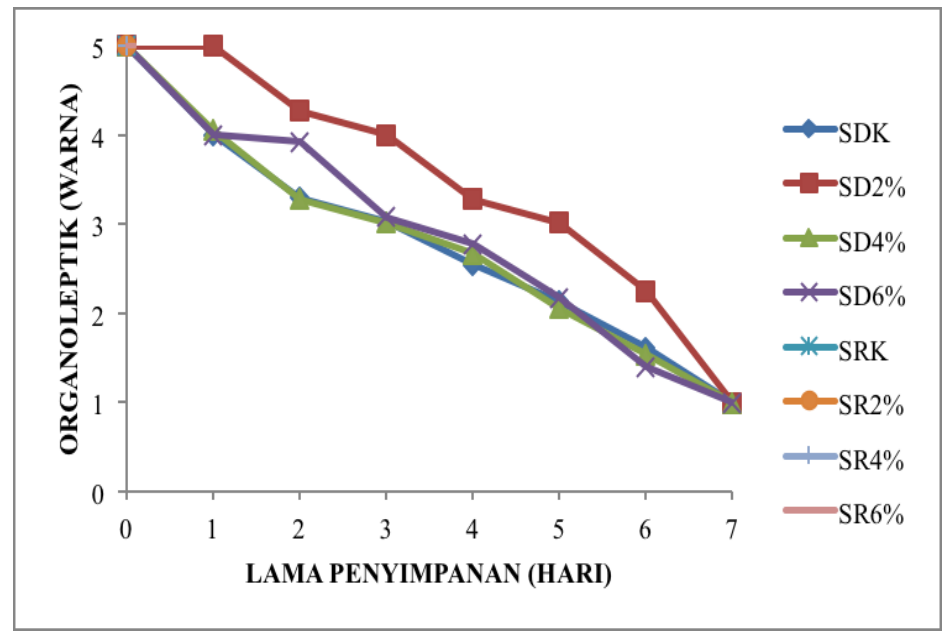

Gambar 6. Penilaian Panelis Terhadap Warna Buah Pepaya Terolah Minimal pada masing-masing Suhu dan Konsentrasi Edible

Rentang nilai yang diberikan panelis terus menurun sehubung dengan lamanya hari penyimpanan. Rata-rata panelis pada hari pertama menyukai semua pepaya yang diberi perlakuan tanpa pelapis, konsentrasi $2 \%, 4 \%$ dan $6 \%$. Hari kedua sampai hari terakhir semua perlakuan yang 
diberikan pada buah pepaya terolah minimal menurun, tetapi buah pepaya terolah minimal yang dilapisi edible konsetrasi $2 \%$ paling banyak disukai oleh panelis. Pada perlakuan kontrol panelis mulai kurang menyukai pepaya pada hari ke- 4 , konsentrasi $2 \%$ panelis mulai tidak menyukai pepaya pada hari ke-6, konsentrasi $4 \%$ panelis mulai tidak menyukai pepaya pada hari ke-4, dan konsentrasi $6 \%$ panelis mulai tidak menyukai pepaya pada hari ke-4. Penyimpanan buah pepaya terolah minimal pada suhu ruang hari ke-0 panelis menyukai semua pepaya yang diberi pelapis dan tanpa pelapis. Hari selanjutnya pengamatan serta pengukuran organoleptik untuk penyimpanan suhu ruang tidak dapat dilakukan lagi, hal ini dikarenakan buah pepaya terolah minimal telah mengalami kerusakan serta telah ditumbuhi jamur.

\section{Rasa}

Penyimpanan suhu dingin buah pepaya terolah minimal yang diberi perlakuan konsentrasi $2 \%$ mempunyai penurunan rasa yang paling rendah dibandingkan dengan perlakuan lainnya seperti terlihat pada Gambar 7. Perlakuan tanpa pelapis adalah pepaya yang tidak disukai oleh panelis. Perlakuan kontrol panelis menyukai sampai hari ke-3, konsentrasi $2 \%$ panelis menyukai sampai hari ke-5, konsentrasi 4\% panelis menyukai sampai hari ke-3 dan konsentrasi $6 \%$ panelis menyukai sampai hari ke-3. Edible coating pati singkong dengan konsentrasi $2 \%$ membuktikan bahwa panelis lebih menyukai rasa dari pepaya terolah minimal. Nilai rasa yang diberikan panelis, menunjukkan bahwa buah pepaya terolah minimal konsentrasi $2 \%$ adalah pepaya yang cocok untuk mempertahankan rasa selama penyimpanan. Penyimpanan buah pepaya terolah minimal pada suhu ruang hari ke-0, panelis menyukai rasa semua pepaya yang diberi pelapis dan tanpa pelapis. Hari selanjutnya pengamatan serta pengukuran organoleptik untuk penyimpanan suhu ruang tidak dapat dilakukan lagi, hal ini dikarenakan buah pepaya terolah minimal telah mengalami kerusakan serta telah ditumbuhi jamur.

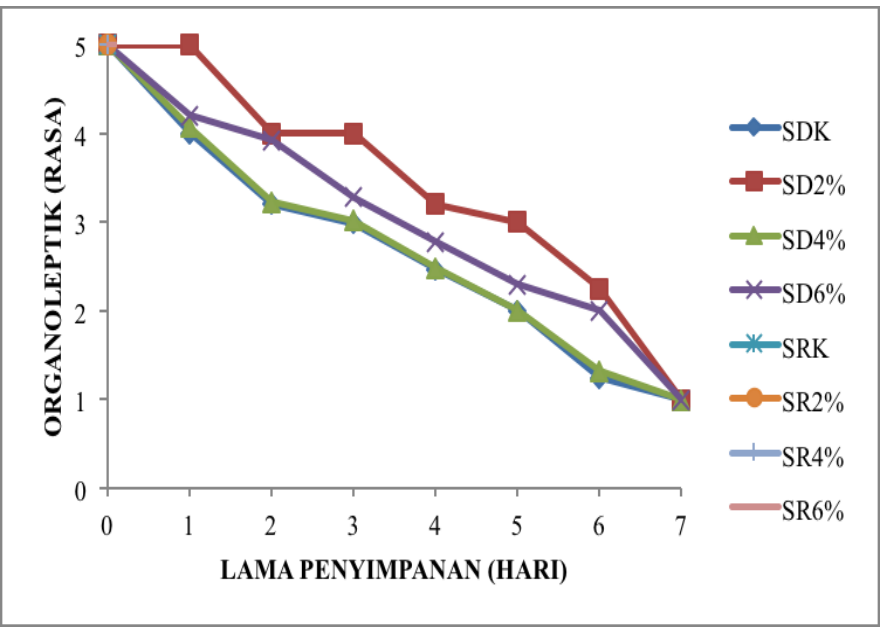

Gambar 7. Penilaian Panelis Terhadap Rasa Buah Pepaya Terolah Minimal pada masing-masing Suhu dan Konsentrasi Edible

\section{KESIMPULAN}

Berdasarkan penelitian pemberian edible coating pada buah pepaya terolah minimal dapat disimpulkan bahwa konsentrasi terbaik untuk mempertahankan mutu buah pepaya terolah minimal selama penyimpanan adalah konsentrasi $2 \%$, suhu terbaik adalah suhu dingin $n$, dapemberian pati singkong sebagai edible coating pada buah pepaya terolah minimal dapat menghambat kerusakan mutu buah pepaya dan memperpanjang umur simpan buah pepaya terolah minimal.

\section{DAFTAR PUSTAKA}

Budiman. 2011. Aplikasi Pati Singkong Sebagai Bahan Baku Edible Coating untuk Memperpanjang Umur Simpan Pisang Cavendish (Musa cavendishii) [Skripsi]. Bogor (ID): Institut Pertanian Bogor. 
Bujianova, Lola. 2017. Studi Konsentrasi Edible Coating dari Kolang-kaling (Arrenga pinnata) untuk Peyimpanan Buah Pepaya (Carica papaya L.) Terolah Minimal. [Skripsi]: Padang (ID): Fakultas Teknologi Pertanian Univeritas Andalas.

Dehya, Mohd. 2015. Aplikasi Edible Coating Berbasis Pati Singkong untuk Memperpanjang Umur Simpan Buah Naga Terolah Minimal [Skripsi]. Bogor (ID): Institut Pettanian Bogor.

Donhowe IG, Fennema. 1994. Edible film and coating: Characteristics, formation, definition and testing methods. Didalam: Krochta JM, Baldwin EA, Nisperos-Carriedo MO, editor. Edible Coating and Film to Improve Food Quality. Technomic Publishing Co. Inc., USA.

Erica, Deby. 2011. Pengaruh Cacl2 Terhadap Warna Dan Cita Rasa Buah Pepaya Kupas Menggunakan Edible Coating Pada Penyimpanan Suhu Kamar [Skripsi]. Padang (ID): Fakultas Teknologi Pertanian Univeritas Andalas.

Fahmy .K dan K. Nakano. 2014 The Individual and Combined Influences of Low Oxygen and High Carbon Dioxide on Chilling Injury Alleviation in Cucumber Fruit. Gifu Univeraity: Enviromental Control In Biology.

Herdiana, N. 2010. Pengaruh Chilling Injury melalui Heat Shock Treatment dan Aloe Vera Coating Buah Tomat (Lycopersicon esculantum Mill) Selama Penyimpanan Dingin [Tesis]. Bogor: Program Pascasarjana, Institut Pertanian Bogor.

Kismaryanti A. 2007. Aplikasi Gel Lidah Buaya (Aloe Vera L.) sebagai Edible Coating pada Pengawetan Tomat (Lycopersicon esculentum Mill.) [Skripsi]. Bogor: Institut Pertanian Bogor.

Krochta JM. 1992. Control of mass transfer in food with edible coatings and films. Didalam: Singh RP, Wirakartakusumah MA, editor. Advances in Food Engineering. CRC Press, USA. Hlm 517538.

Mardiana, Kiki. 2008. Pemanfaatan Gel Lidah Buaya Sebagai Edible Coating Buah Belimbing Manis (Averrhoa carambola L.) [Skripsi]: Bogor: Fakultas Teknologi Pertanian Bogor Institut Pertanian Bogor.

Megaria, Ratna Aprilyanda. 2011. Pengurangan Gejala Chilling Injury Buah Belimbing (Averrohoa carambola.L) Dengan Perlakuan Alovera Coating. [Skripsi]. Bogor: Institut Pertanian Bogor.

Pujimulyani, Dwiyati. 2009. Teknologi Pengolahan Sayur-sayuran dan Buah-buahan. Grada Ilmu: Yogyakarta.

Rudito. 2005. Perlakuan Komposisi Gelatin dan Asam Sitrat dalam Edible Coating yang Mengandung Gliserol pada Penyimpanan Tomat. Jurnal Teknologi Pertanian, vol 6 (1): 1-6.

Sari, Rita Nopita, Novita Dwi Dia, Sugianti Cicih. 2015. Pengaruh Konsentrasi Tepung Karagenan dan Gliserol Sebagai Edible Coating Terhadap Perubahan Mutu Buah Stroberi Selama Penyimpanan Selama Penyimpanan. Jurusan Teknik Pertanian Universitas Lampung. Vol 4, No. 4: 305-314.

Sugito, Asep. 2014. Pengaruh Konsentrasi Pelapisan Edible (Edible Coating) dari Gel Lidau Buaya (Aloe Vera, L.) dan suhu Penyimpanan terhadap Mutu Buah Melon (Cucumis melon, L.) Terolah Minimal [Skripsi]. Padang (ID): Fakultas Teknologi Pertanian Univeritas Andalas.

Winarno FG, Wirakartakusumah MA. 1981. Fisiologi Pasca Panen. Jakarta (ID):PT. Gramedia.

Winarno, F.G. 2002. Kimia Pangan Dan Gizi. PT. Gramedia Pustaka Utama: Jakarta. 